\title{
Tourism Development in Banda Aceh City \\ (A Study of Tourism Policy Implementation Based on Aceh Qanun Number 8 of 2013 concerning Tourism)
}

\author{
Said Mayzar Mulya ${ }^{1}$, Agus Sholahuddin ${ }^{2}$, Sri Hartini Jatmikowati ${ }^{3}$ \\ 1,2,3 Universitas Merdeka Malang, Malang, Indonesia \\ Sayed.Mayzar@gmail.com
}

\section{Abstract}

Tourism is a large economic sector and is very competitive at all levels - local, national, regional and international because of the benefits it brings and its contribution to the economy for urban development. Tourism development in each region, especially Banda Aceh City, should be well focused. Because the development in this sector challenges, movements and shifts will be very dynamic, so they must be continuously managed. This study uses a post positivist approach with data collection methods through literature, and in-depth interviews to find out Tourism Development in Banda Aceh City, the uniqueness of tourism in Banda Aceh City, as well as the factors that support and obstacles in implementing the Tourism policy in Banda Aceh City. The results of the study note that Tourism Development is a major work that must always be overseen planning and implementation that is formed with the development, infrastructure, promotion and marketing, structure (different organizations) and scale (international, national, local and sectoral).

Keywords policy implementation; tourism development; tourismpolicy

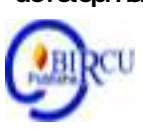

\section{Introduction}

Indonesia is a country that has the potential to advance and develop in the tourism sector. Tourism has an important role in increasing the income of a region or country. In addition, tourism is also one way to introduce the culture of an area to other regions. The tourism industry also contributes to social and economic development, both in developed and developing countries.

Tourism is a travel activity carried out by a person or group of people by visiting certain places supported by various facilities for recreational purposes, personal development, or learning the uniqueness of the tourist attractions that are visited, in a temporary period (Ismayanti, 2000).

Tourism is basically a travel activity and / or activities carried out by a person or group of people by visiting a particular place for recreational purposes, personal development, or learning the uniqueness of the attraction of a tourist attraction visited in a temporary period, and a certain time.

The role of the regional government as a tourism facilitator is very strategic in realizing efforts towards the development of tourism through the leadership of the institution, with responsibility for 4 (four) main things through planning (planning) in the form of a Regional Tourism Master Area (KIPDA) or tourism area, development of main facilities and supporting tourism both facilities and means, policy expenditure as a zone restriction as a tourist attraction and tourism object restrictions with 
a variety of sharia activities, and the creation and enforcement of regulations by involving stakeholders and the community as a fortress travel.

The tendency of the development of regional tourism will affect national tourism and at the same time affect world tourism from year to year showing the development of Aceh City with various natural attractions and artificial tourism. This is caused by a change in the socioeconomic structure of the country in the world which is getting more and higher income. On the other hand, this literacy becomes a basic need in the life of global phenomena and is made an object of human rights that must be protected and respected by the state and region.

When viewed from a broader perspective of life, tourism also has a significant role in strengthening and enhancing the quality of relations between people and between nations so that there is better mutual understanding and social cohesion, mutual respect, friendship, promoting solidarity and nationalism, even to the point of at the level of world peace.

In developing tourism, Indonesia still faces many obstacles. Among these, the main ones are infrastructure, connectivity and transportation, especially airports of international standard so that flights can be directly from the source countries of foreign tourist markets to destinations in the country and seaports that can be harbored by cruise ships. In addition, the quality of Indonesian tourism products that have not yet developed in accordance with market desires.

The influence of government intervention on the development of tourism in an area can be done by applying some incentives in developing substainable tourism in the future, namely by way of land use regulations, limiting tourists to areas prone to damage to ecosystems, protecting local culture in various ways, directing tourist behavior to be more environmentally friendly, limiting the use of non-renewable energy, being able to save scarce resources, reducing pollution and also not forgetting incentives for the development of useful infrastructure such as transportation systems, protection of green spaces and national parks .

This is also not spared from the efforts made by the Government of Aceh to further introduce Aceh as a world tourist destination. The development of tourism is essentially an effort to develop and utilize tourist objects and attractions that are realized, among others in the form of beautiful natural wealth, diversity of flora and fauna, diversity of traditions and cultural arts, and ancient relics.

As one of the economic sub-sectors, tourism growth plays an important role in Aceh's economy. If natural resources are managed properly, they will be able to become the mainstay of the national economy, especially when viewed with the geographical condition of Aceh, which is located at the western end of Sumatra and the western end of Indonesia.

Tourism resources are one form of potential resources that can be developed into one economic unit through tourism activities. With this tourism activity, if professionally managed and developed it will be able to create a multiplier effect in the economy of the region concerned (Ross, 1998 quoted by Rompon, 2006: 754).

There are several superior characteristics of the tourism industry that cause this industry to be able to act as a booster for a country's economic growth, including as (Ross, 1998 quoted by Rompon, 2006: 754) states as follows:

1. The tourism sector is an industry that has a very long multiplier effect and is able to establish growth synergies with various micro businesses including home industry activities.

2. Tourism businesses are able to absorb a lot of local resources (local resource based) and are mainly made from raw materials that are relatively never used up or can be renewed (renewable resource). 
3. In the tourism industry there is no over power supply because it has unique product characteristics, which are relatively unaffected by the recession / economic crisis situation in a country.

This industry also has a very strategic specific character as an instrument for equitable regional development and community empowerment, especially those who live in rural and even remote areas. In addition to providing equitable development, this industry also provides an increase in welfare and community empowerment, not only in the material and spiritual aspects of welfare but also able to improve the cultural and intellectual welfare of the community.

Emphasis made in the translation of nature conservation of tourist objects as well as destinations that already exist are addressed to be useful objects that produce government funds to provide funds for regional tourism objects as in articles 57, 58 and 59 of Law Number 10 of 2009 concerning Tourism, mention as following:

1. Article 57, Tourism funding is a joint responsibility between the Government, Regional Governments, entrepreneurs, and the community.

2. Article 58, the management of tourism funds is based on the principles of fairness, efficiency, transparency, and public accountability.

3. Article 59, the Regional Government allocates a portion of the income derived from the implementation of tourism for the benefit of nature and cultural preservation.

Tourism resources are one form of potential resources that can be developed into an economic unit through tourism activities. The development of tourism in Indonesia is arguably increasing rapidly, the number of tourists each year has increased with the opening of new transportation lines in order to attract potential tourists. The tourism industry has also been proven to contribute significantly to national economic development, especially its role in the instrument for increasing foreign exchange earnings outside of oil and gas, forest products and mining which according to estimates from experts has begun to decline.

There are many tourism problems that are still a problem in Indonesia, especially in Aceh. As for this matter, it becomes homework (PR) to be completed immediately in all tourist destinations throughout Indonesia, namely facilities and infrastructure. This problem is also a scourge that should not be spared from the discussion in every policy making effort regarding tourism.

The tourists enter Aceh region with various modes of transportation, one of which is a favorite is the aircraft. Until now aircraft transportation modes only serve the routes of Jakarta, North Sumatra, Kuala Lumpur and Penang, so there is still a perceived lack of attractive routes resulting in increased tourist visits.

\section{Review of Literature}

On the implementing, problems can arise when a theory will be put into practice. That is because there is no correlation between theory and practice or even field conditions. If under certain conditions it turns out that the necessary theory is not found, then it takes courage to innovate to form a new theory that can be used as a guide for policy making and implementation. In today's modern life, good tourism development and development activities will not run well without a good policy. Within the scope of the Central Government and Local Governments must be able to have a deep understanding of the importance of developing and implementing good policies in tourism. 


\subsection{Policy Implementation}

If we look at the implementation of public policy is an action that includes efforts to change decisions into operational actions within a certain period of time and in order to continue efforts to be able to pass small and large changes determined by policy decisions, as Meter and Horn in Winarno (2012) stated that "Implementation of public policy as actions in previous decisions".

A policy that has been tapped for approval will still contain doubts, whether the problem faced can be resolved properly in accordance with expectations and whether the policy has been implemented, implemented properly as desired by policy makers. In addition, policy implementation is also influenced by the nature of the policy itself, where the environmental conditions and conditions of the community receiving the policy.

Some countries have prepared their experts to develop superior public policies to strengthen the capacity of the state in an effort to strengthen the country itself, in order to build a better country. In other words as Dye in Sadhana (2011) mentions the following:

"A policy or program must be implemented so that it has the desired impact or goals. In a broad sense, policy implementation is seen as a public administration tool in which actors, organizations, procedures, technical and resources are jointly organized to carry out policies in order to achieve the desired impact or goals ".

Based on the description above, Agustino (2008) concludes that: "Implementation is a dynamic process, whereby the implementer of the policy carries out an activity or activity, so that in the end it will get a result that is in accordance with the goals or objectives of the policy itself."

In this study, the authors tend to use the theory of George Edward III, because if it is adjusted to the problem in research that in carrying out the implementation problem approach poses 2 (two) main questions in line with the formulation of the problem raised by the author namely:

1. What factors support the successful implementation of the policy?

2. What factors hinder the successful implementation of the policy?

Based on these two questions, Edward III formulated 4 factors which are the main conditions in the successful implementation process. The four conditions are as illustrated in the following chart:

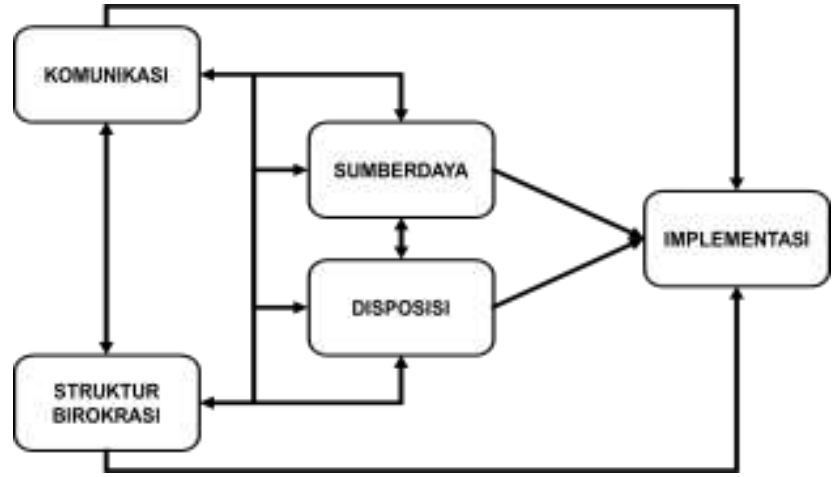

Figure 1. Factors that Influence Public Policy Implementation

a. Communication

The success of a policy requires that the implementor knows what needs to be done. Communication is related to the delivery of information, ideas, skills, and others using a certain means. According to Edwar III in Widodo (2001), communication is also defined as "the process of delivering communicator information to the communicant". 
Communication itself is a measure of how far a policy formed in a regulation has been conveyed clearly and has the same interpretation and can be implemented consistently with the implementing apparatus.

\section{b. Resources}

The resources referred to here can be in the form of human resources and can also be in the form of financial resources. According to Edward III in Widodo (2001) "no matter how clear and consistent implementation of orders are and no matter accurately they are transmitted, if personnel are responsible for carrying out policies lacking the resources to do an effective job, implementing will not be effective". The important human resources include: having sufficiency and qualifications, having authority, having information and having facilities and infrastructure.

\section{c. Disposition / Attitude}

The intended attitude in this case is the attitude of the implementers who support the implementation of a policy that has been determined. According to Winarno (2012), if the supervisors behave well toward a particular policy, in this case it means there is support, they are more likely to implement the policy as desired by the initial decision makers, and vice versa if the behavior or perspectives of the implementers differ from the decision makers, then the process of implementing a policy becomes more difficult. Disposition can also be said as the character and characteristics possessed by the implementor such as commitment, honesty and democratic nature.

\section{d. Bureaucratic Structure}

A policy will be implemented by a bureaucratic structure and have a significant influence. In every organization, an important structural aspect is standard operating procedures as they are often referred to as SOPs. But the SOP itself has a weakness that can hinder the implementation of new policies that require work methods or certain types of personnel and are new to implementing policies. In addition to its weaknesses, SOPs also have advantages in which organizations with good planning procedures will produce good control and can be in line with the program of activities that enable them and officials to make more adjustments to new responsibilities.

Implementation as an effort to create relationships that allow the objectives of the policy can be realized as a result of government activities. These efforts are designed with a hope of realizing the expected outcome. Thus the policy implementation is a crucial stage in the process of implementing a new system, a policy system must be implemented so that it has the desired impact or objectives.

\subsection{Tourism Development}

The concept of development, having the meaning of rules, strategies and targets for the development or promotion of tourism must lead to a process of change based on the desires of a nation society. Theoretically tourism development planning according to Inskeep in Sunaryo (2013) is "a process to prepare systematically and rationally all activities or tourism activities that will be carried out to achieve a certain goal and is a way to achieve these goals optimally by allocating all resources available effectively and efficiently". Tourism development planning certainly has a very strategic role in providing future development directions that are able to place the tourism sector as one of the pillars that sustain national economic development, regional development and community empowerment. 
Table 1. Paradigm Shift and Stratey of Tourism Development

\begin{tabular}{|c|c|c|}
\hline \multirow{2}{*}{ Characteristics } & \multicolumn{2}{|c|}{ Tourism Development Paradigm Orientation } \\
\hline & Growth & Sustainable \\
\hline Focus & Growth : Mass Tourism & Development \\
\hline $\begin{array}{l}\text { The value being } \\
\text { pursued }\end{array}$ & $\begin{array}{l}\text { Foreign exchange and } \\
\text { investment }\end{array}$ & $\begin{array}{l}\text { Community Based \& Green } \\
\text { Tourism }\end{array}$ \\
\hline Indicator & $\begin{array}{l}\text { Number of visits, length of } \\
\text { stay and tourist spending }\end{array}$ & The multi-impact of tourism \\
\hline $\begin{array}{l}\text { Government's Role } \\
\text { Community Role: }\end{array}$ & Enterpreneur \& Developer & Facilitator \\
\hline Access & Closed & Open \\
\hline Role & Passive & Active-participatory \\
\hline Character & Beneficiaries & Entrepreneur \\
\hline Position & Marginal & Stakeholder \\
\hline Quality Demands & Local Standards & Universal Standards \\
\hline
\end{tabular}

The table clearly shows a significant difference where the government previously collaborated with the private sector is now the main actor in the tourism development process. While the role of the community which was previously passive and often marginalized, is now active and has become one of the stakeholders.

The independence of tourism development is one that is being emphasized by Indonesia's growth with the inclusion of the tourism sector in the Indonesian Mission 2030. Conceptually, the independence of the development of the tourism sector in Indonesia can be understood as an effort to realize existing tourism development programs that are systematically designed so that individuals and Indonesian people can be the subject of tourism development itself.

\section{Research Methods}

The location of the study was carried out in Banda Aceh City, Aceh Province. Aceh is located on the northwestern tip of Sumatra Island with the capital city of Banda Aceh which has a strategic position as a gateway for national and international trade traffic that connects the eastern and western parts of the world.

Based on the research background, the authors were interested in knowing and analyzing the tourism policy strategy undertaken by the Government of Aceh and the factors that influence the development of tourism in the Province of Aceh, especially in Banda Aceh City area.

Data collection in this study was obtained through sources and types of data using data collection techniques. Data is an important factor in research for that certain techniques are needed in data collection.

In the interactive method, researchers deliberately choose in-depth interviews, while the non-interactive method of researchers is more oriented to the existence of documents or archives in the Government of Aceh. Researchers systematically search for and process various data sourced from interviews, observations, fieldwork and document review (literature) to produce reports on research findings.

In data analysis techniques in a study is data that has been collected which in turn will be analyzed using descriptive analysis that is interactive analysis models in accordance with the views of Miles, Huberman and Saldana (2014) states that "Activities in qualitative data analysis are carried out interactively, take place continuously until complete, so that the data 
is already saturated. Activities in data analysis, namely data reduction, data display, conclision drawing / verification.

The interactive analysis method is a research not an experiment, so it is not intended to determine the effects of a treatment. Thus, in a descriptive study only researchers intended to describe or explain the symptoms that are happening so that the findings can be understood and informed to others.

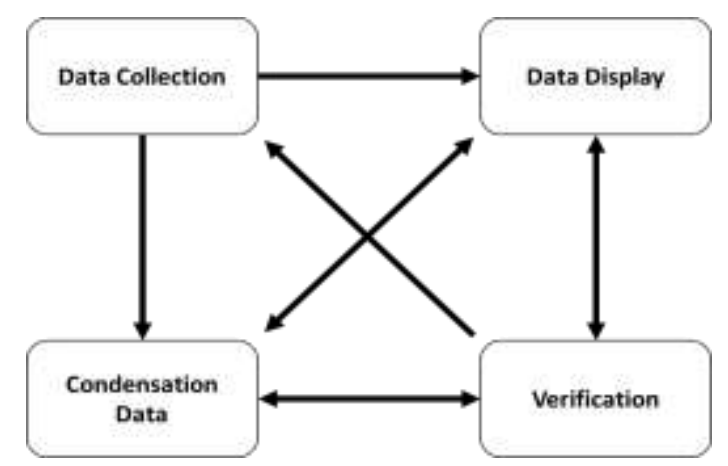

Figure 2. Qualitative Data Analysis through Interactive Analysis

The use of descriptive analysis through an interactive analysis model in accordance with the views of Miles, Huberman and Saldana (2014) states that "activities in qualitative data analysis are carried out interactively, so the data analysis techniques in a study constitute processed data covering three steps, namely condensation data, data display, and making conclusions / verification ".

\section{Discussion}

\subsection{Overview}

Banda Aceh City has a very strategic position with countries in the southern part of the Asian Continent and is also the westernmost gateway to the territory of the Republic of Indonesia. This potential will become an asset for Banda Aceh City in particular and become a great potential both naturally and economically so that Aceh Province can be more open to the influence of the surrounding area and the outside world or more to introduce and grow the image and identity in national and international events.

In this regard, the leading tourism potential of Banda Aceh City if detailed consists of various sectors that are expected to contribute to regional development, the tourism potentials include:

Table 2. Number of Tourism Development Objects and Sites in Banda Aceh City

\begin{tabular}{lc}
\hline \multicolumn{1}{c}{ Objects / Site } & Total \\
\hline Historical Objects & 17 \\
Monument & 6 \\
The gardens & 3 \\
Tsunami Tourism Objects & 7 \\
River & 2 \\
Beach Objects & 4 \\
Historical Mosque & 5 \\
Tomb / Tomb Complex & 38 \\
TOTAL & $\mathbf{8 2}$
\end{tabular}




\subsection{Potential Development of Tourist Destimations}

Law Number 10 of 2009 concerning Tourism which has been rolled out for 10 years by the Government and subsequently the Government of Aceh has also stipulated the Aceh Qanun Number 8 of 2013 concerning Tourism. It is still not able to accommodate the demands of the times for the development of a very dynamic tourism that continues to move forward. So that it takes the role of all resources to provide input and encouragement to the Aceh government, especially Banda Aceh City Government to be able to establish policies that can accommodate all demands in tourism.

From the overall development of tourism, basically a policy set by the government is not a single decision, but rather consists of several choices of actions and strategies. The government as the regulator must be able to reach the other four elements of the resource. By utilizing and utilizing all existing elements, so that it will be able to respond to everything related to the needs of tourism development in a destination, especially Banda Aceh City.

The key in the grand strategy of developing tourist destinations in the current era is Human Resources (HR). The role of HR is a very strategic factor, especially in the tourism sector whose business characteristics are more service-oriented. Increasing human resources is also an obligation that must be carried out very well to achieve sustainable tourism development. The level of public education and supporting programs that have been developed around attractions is quite a challenge. Because, how the level of resources possessed will largely determine everything related to tourism.

Since the tsunami disaster on December 26, 2004 caused by an earthquake of 9.2 on the Richter Scale around the Indonesian Ocean. This disaster claimed hundreds of thousands of inhabitants and destroyed more than $60 \%$ of the city's buildings and in the absence of armed conflict that had continued to haunt the Aceh region, many tourists began arriving in Aceh. In its development tourist attractions / tsunami sites became the focus in tourism development and resulted in an economic improvement and revitalized many creative industries of the community, with increasing numbers of tourist visits to Banda Aceh.

Based on tourism statistics in 2019, most tourist visits were recorded to be dominated by tsunami attractions, mosque attractions and grave attractions. After the tsunami in 2004 to date, many development efforts have been undertaken by the regional government. The following data is obtained from the Banda Aceh City Department of Tourism.

Table 3. Tourist Visits on Mainstay Objects

\begin{tabular}{llllll}
\hline \multirow{2}{*}{ Favorite Tourist Objects } & \multicolumn{5}{c}{ Years } \\
\cline { 2 - 6 } & 2015 & 2016 & 2017 & 2018 & 2019 \\
\hline Boat Over the House & 80.272 & 30.979 & 74.276 & 78.177 & 127.231 \\
Floating PLTD & 565.413 & 244.335 & 488.235 & 510.402 & 368.831 \\
Tomb of Tgk.Syiah & 37.447 & 5.407 & 51.867 & 48.219 & 52.730 \\
$\begin{array}{l}\text { Kuala } \\
\text { Baiturrahman Grand }\end{array}$ & 8.720 & 2.721 & 38.600 & 31.447 & 34.007 \\
$\begin{array}{l}\text { Mosque Robe Counter } \\
\text { Ulee Lheue Information }\end{array}$ & 946 & 181 & 644 & 335 & 165 \\
$\begin{array}{l}\text { Center } \\
\text { Aceh Tsunami Museum }\end{array}$ & - & - & - & 744.205 & 532.054
\end{tabular}

Based on the table above, the tourism development potential of tourism objects is focused on tsunami tourism objects. In the development of these tourist objects continue to get renewed by doing building rehab, adding material, adding events, and adding promotions in other tourism activities. 
One of them is a tourist attraction PLTD floating, this attraction is a tsunami site that was previously a PLTD (diesel power plant) in the form of ships and located in the ocean that serves to provide electricity for Banda Aceh City, especially the Ulee Lheue region.

However, after the tsunami, the 2,600-ton ship was dragged by waves as high as 9 meters and shifted as far as $5 \mathrm{Km}$ towards the city, precisely at the Blung Cut Pungee Village. When the incident occurred, from a total of 11 crew members and a number of residents around who were on board only 1 person who survived. The shift of this ship to the middle of the city is a phenomenon that proves how powerful the tsunami waves that occurred at that time.

Currently the ship still stands firmly but is no longer functioning as a PLTD, this is due to the transfer of rights from the assets of PT. PLN is a Government asset. Now, the ship is converted into a monument as well as a museum that provides education to visitors related to the origin of the ship and the cause of the tsunami.

Around the ship, built a memorial monument that listed the date and time of the incident and around the memorial monument was also built a wall with reliefs resembling a tsunami wave and also an educational park equipped with photos and information about the 2004 Aceh tsunami that can also be enjoyed by visitors. At the top of the ship, visitors can also enjoy views of Banda Aceh city from a height and also provided 2 pieces of binoculars that can be used.

The construction of other attractions is landscaping or green open space. Some parks in Banda Aceh city that have not yet been extensively developed are the Blangpadang field, this is because this field is designated as a green open space so it is not allowed to build other buildings that reduce the area where plants grow and also because there are still land disputes over Blangpadang land assets between Aceh Provincial Government with the TNI.

This field has an area of 8 hectares which is close to the Baiturrahman Grand Mosque which is actually included in one of Aceh's historical sites because it has a history that is intertwined with attractions around it. In this field, urban communities often do sports activities and enjoy culinary and children's playground. In this vast field, there are other attractions, namely the "thanks to the world" monument which is a monument consisting of 80 inscriptions in the shape of a half-boat and written words of thanks to countries that have been involved in Aceh's post-tsunami recovery program and the Dakota Seulawah monument 001 or under another name RI-001 aircraft purchased by the people of Aceh for the Government of Indonesia and is the forerunner of the first Indonesian airways aircraft company. Despite the unclear ownership of Blangpadang Field assets, this place remains a hub for various major events in Aceh.

The population of Banda Aceh City in 2018 was around 265,111 people, population aged 15 years and over in Banda Aceh City as many as 201,735 people included in the workforce as many as 121,477 people so that if it was reduced to 60.22 percent (Source of BPS data for 2019). From these data it can be seen that almost half of the population of Aceh is young men and women who will later develop Aceh in the future.

These young people are empowered with knowledge that is able to increase their potential so that they are able to compete with other communities and can participate directly in the entire tourism process both in formulating or implementing tourism with a variety of diversity and local wisdom in the area.

Developing creativity and inviting young women to learn by creating an atmosphere that utilizes their potential to act together in trying to solve a problem that occurs in society.

The basic thing that can make a community empowered is an increase in the level of education, health status, and access to sources of economic progress such as capital, technology, market information and employment. 
With the involvement of the local community is expected to directly provide economic benefits from tourism that occurs in an area, especially tourist destinations in Banda Aceh City.

Tourism has also proven to be able to improve the economy and industrial development, for example, the proliferation of coffee shops in various types and allotments, making the business accelerate in the past few years. This is in line with the lifestyle trends of generations $\mathrm{Y}$ and $\mathrm{Z}$ which dominate the population and create a new lifestyle of hanging out while drinking coffee and the presence of social media making it easier for business people to do marketing and promotional activities as well as the presence of an online shipping service platform. In addition, the distribution of the availability of raw material supplies, equipment, and resources is getting better and better. Just as with coffee shops, restaurants and cafes exist and at the same time coffee shops provide a special attraction with the various offers on offer. It was noted that Banda Aceh City until 2018 had a total of 295 Cafes and Warkop as well as 272 restaurants and restaurants.

\section{Conclusion}

In simple terms, tourism is a traveling practice and also a business providing products, services and related facilities. Tourism is a large and highly competitive economic sector at all levels - local, national, regional and international. Tourism offers economic, social, cultural, intellectual, political and environmental benefits.

The implementation of Aceh's tourism aims to preserve, promote, utilize and improve the quality of tourism attractiveness that is able to elevate the historical and cultural values of Aceh based on Islamic Sharia as a special attraction as a differentiator or a special value, can expand work space and equalize opportunities in endeavor, and in the end be able to increase the Regional Original Income towards the welfare and prosperity of the people and to realize Banda Aceh City as a Cultural and Religious Based Tourism Destination.

The natural disaster of the Tsunami that occurred in December 2004 which claimed hundreds of thousands of inhabitants and devastated Banda Aceh City to over $60 \%$ of the city's buildings were destroyed. Making Banda Aceh City a unique feature that can be highlighted in terms of tourism. Namely by optimizing attractions that are directly related to the Tsunami, such as tsunami education, tsunami museums, tsunami relics and so forth.

Tourism development in each region, especially Banda Aceh City, should be well focused. Because the development in this sector challenges, movements, and shifts will be very dynamic, so they must continue to be monitored.

Tourism planning should take place in the form of development, infrastructure, promotion and marketing, structure (different organizations) and scale (international, national, local and sectoral). The suggestions that can be proposed are as follows:

1. Propose a revision or amendment to Aceh Qanun Number 8 of 2013 concerning Tourism because it is felt that it has not been able to accommodate the needs in the implementation of tourism by referring to the current development of tourism.

2. Immediately prepare Banda Aceh City Qanun related to Regional Development Master Plans in accordance with Government Regulation Number 50 of 2011 concerning Tourism Development Master Plans for 2010-2025.

3. Connectivity between transportation access is still one of the crucial issues that must be addressed immediately because access to Banda Aceh City is currently only land transportation (private car / rental / bus) and air transportation (6 airlines) with Medan flight routes - Jakarta - Kuala Lumpur - Penang. In the future it is hoped that more 
transportation options and even new routes will be opened so that tourists will have more alternative transportation.

4. The application of Islamic Sharia established in the daily life of the people of Aceh is also a special attraction, many tourists are interested in visiting Islamic heritage sites in the past even sometimes tourists are interested in learning Islam itself.

5. Tourist objects and attractions that are sold are easily reached by tourists so that the percentage of tourists who will visit will be higher.

6. The cluster pattern is held which is a combination of 2 or 3 regencies / cities in the development of tourism so that the focus is not divided and tourists can more easily access as they wish.

\section{References}

Agustino, L. (2008). Dasar-dasar kebijakan publik. Bandung: Alfabeta.

Anderson, J. E. (1975). Public Policy-Making [By] James E. Anderson. Praeger.

Cochran, C. L., \& Malone, E. F. (1999). Public policy: Perspectives and choices (p. 46). Sydney: McGraw-Hill College.

Dunn, W. N. (2010). Pengantar Analisis Kebijakan Publik Edisi Kedua. Yogyakarta: Gajah Mada University.

Edward III, G. C, 1980, Implementation Public Policy.

Ismayanti, I., Materi, P., Instruksional, P. D., Kover, P., Letak, I. P., Djamhur, I. G., ... \& Satyarini, M. N. W. M. (2000). Pengantar Pariwisata.

Miles, M. B., Huberman, A. M., \& Saldaña, J. (2014). Qualitative data analysis: A methods sourcebook. 3rd. ed: Thousand Oaks, CA: Sage.

Moleong, L. J. (2009). Metodologi Penelitian Kualitatif, Bandung: PT Remaja Rosdakarya Offset.

Riant, N. (2014). Public policy. Elex Media Komputindo, Jakarta.

Sunaryo, B. (2013). Kebijakan pembangunan destinasi pariwisata: konsep dan aplikasinya di Indonesia (No. 1). Penerbit Gava Media Kebijakan Pembangunan Destinasi Pariwisata: Konsep dan Aplikasinya di Indonesia.

Widodo, J. (2001). Implementasi Kebijakan. Bandung. Pustaka Pelajar.

Winarno, B. (2012). Kebijakan publik: teori, proses, dan studi kasus: edisi dan revisi terbaru. Center for Academic Publishing Service. 